\title{
Poligami: Antara Teks dan Konteks Sosial
}

\author{
Moh. Mukri
}

\begin{abstract}
Polygamy: Between The Text and Socio Historical Context. This article discusses the proposition of Syara' concerning polygamy. The aim is to find out the relationship between literal meaning of the text and the socio-historical context underlying the issuance of the provosion. This study utilizes historical, textual approach to obtain a vivid, comprehensive perspective of the literal and contextual meaning. As it is already known, the proposition of polygamy is Surah an-Nisa': [4]: 3 plus a number of hadiths relating the issue. According to history, the reasons underlying the revelation of Surah an-Nisa': [4]: 3, actually, was to reprimand companions who wanted to marry orphans in their guardianship but unwilling to give dowry as much as when they married other women. Thus, the verse was not solely about polygamy or limitation of the number of wives, but it also contained a criticism against contemporary tradition which tended to be arbitrary in releasing lust. Furthermore, polygamy itself is not recommended nor even impulsive in Islam. As the above-mentioned shura implies, Islam prefers monogamy than polygamy, as it imposes difficult condition for those who want to do polygamy.
\end{abstract}

Keyword: polygamy in Islam

\begin{abstract}
Abstrak: Poligami dalam Konteks Nas. Artikel ini membahas dalil Syara tentang poligami. Tujuannya untuk mengetahui hubungan antara makna harfiah teks dengan konteks sosio-historis yang mendasari penerbitan ketetapan tersebut. Penelitian ini menggunakan pendekatan historis, tekstual dan kontekstual untuk memperoleh perspektif yang jelas dan komprehensif tentang makna harfiah dan konteks suatu dalil. Seperti yang sudah diketahui, dalil tentang poligami dalam al-Qur an adalah Surah an-Nisa': [4]: 3 ditambah sejumlah hadits yang berkaitan dengan masalah tersebut. Menurut sejarah, alasan yang mendasari turunnya Surah an-Nisa': [4]: 3, sebenarnya, adalah untuk menegur sahabat yang ingin menikahi anak yatim piatu dalam perwalian mereka tetapi tidak mau memberi mas kawin sama seperti ketika mereka menikahi wanita lain. Dengan demikian, ayat itu tidak semata-mata tentang poligami atau pembatasan jumlah istri, tetapi juga mengandung kritik terhadap tradisi kontemporer yang cenderung sewenang-wenang dalam melampiaskan nafsu. Lebih jauh lagi, poligami itu sendiri tidak disarankan atau bahkan diwajibkan dalam Islam. Lebih jauh lagi, poligami itu sendiri tidak dianjurkan atau bahkan diwajibkan oleh Islam. Seperti disebutkan secara implisit dalam ayat di atas, Islam lebih memilih monogami daripada poligami, karena itu membebankan kondisi sulit bagi mereka yang ingin melakukan poligami.
\end{abstract}

Kata Kunci: poligami dalam Islam

Universitas Islam Negeri Raden Intan Lampung

Jl. H. Endro Suratmin Sukarame

E-mail:mmukri@radenintan.ac.id 


\section{Pendahuluan}

Secara etimologi kata poligami berasal dari bahasa Yunani, poly atau polus yang berarti banyak dan gamein atau gamos yang berarti kawin atau perkawinan. Jadi secara bahasa, poligami berarti "suatu perkawinan yang jumlah istrinya banyak" atau "suatu perkawinan yang lebih dari seorang", baik pria maupun wanita. Poligami bisa dibagi menjadi dua pengertian yakni poliandri dan poligini. Poliandri adalah perkawinan seorang perempuan dengan lebih dari seorang laki-laki. Sedangkan poligini adalah perkawinan seorang laki-laki dengan lebih dari seorang perempuan. ${ }^{1}$ WJS. Poerwadarminta mengartikan poligami sebagai adat seorang laki-laki beristri lebih dari seorang. ${ }^{2}$ Sementara dalam konteks agama Islam, poligami diistilahkan dengan ta'addud al-zawjah. Poligami dalam pandangan al-madzâhib al-'arba'ah yakni Imâm Abû Hanîfah, Imâm Mâlik, Imâm Syâfîî, dan Imâm Aḥmad, hukumnya adalah mubah. ${ }^{3}$ Dasar dari poligami secara normatif, terdapat dalam Surat al-Nisâ [4] ayat 3 yang berbunyi:

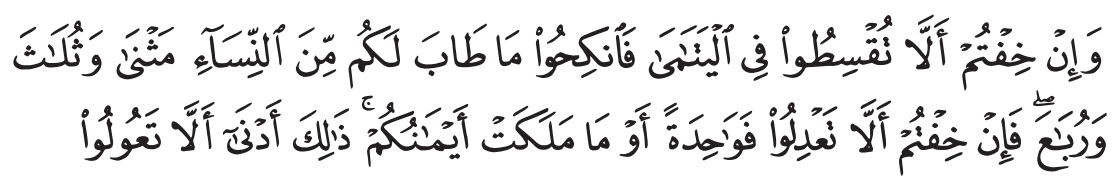

“...dan jika kamu takut tidak akan dapat berlaku adil terhadap (hakhak) perempuan yang yatim (bilamana kamu mengawininya), maka kawinilah wanita-wanita (lain) yang kamu senangi: dua, tiga atau empat. Kemudian jika kamu takut tidak akan dapat berlaku adil, maka (kawinilah) seorang saja, atau budak-budak yang kamu miliki. Demikian itu adalah lebih dekat kepada tidak berbuat aniaya".

Selain itu, dijelaskan juga dalam firman Allah Alquran Surat al-Nisầ [4] ayat 129:

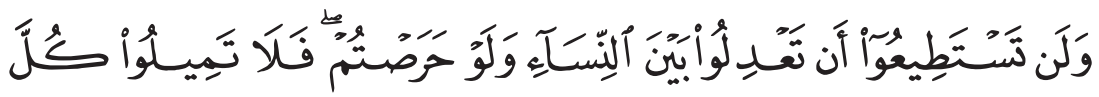

\footnotetext{
${ }^{1}$ Dewan Redaksi Ensiklopedi Islam, "Ensiklopedi Islam," 4 (Jakarta: PT. Ichtiar Baru Van Hoeve, 1994), h. 107.

2 W.J.S Poerwadaminta, Kamus Bahasa Indonesia (Jakarta: Balai Pustaka, 1976), h. 763.

${ }^{3}$ Lihat selengkapnya Abdurrahaman Al-Jaziry, al-Figh Alâ al-Madzâhib al-Arba' ah, IV (Bayrut: Darul Fikr, 1996).
} 


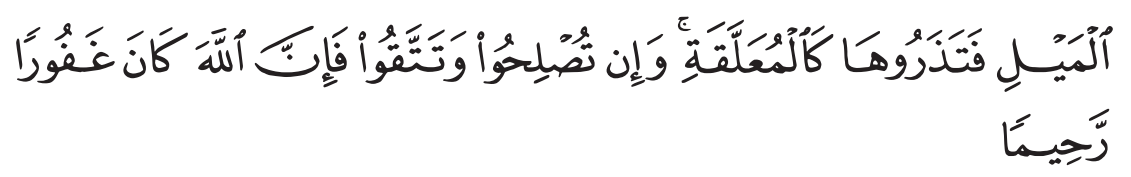

“...dan kamu sekali-kali tidak akan dapat berlaku adil di antara isteri-isteri (mu), walaupun kamu sangat ingin berbuat demikian, karena itu janganlah kamu terlalu cenderung (kepada yang kamu cintai), sehingga kamu biarkan yang lain terkatung-katung. Jika kamu mengadakan perbaikan dan memelihara diri (dari kecurangan), maka sesungguhnya Allah Maha Pengampun lagi Maha Penyayang”.

Berbagai kajian telah mengupas tentang poligami, baik dari pemikiran tokoh maupun dalam perspektif berbeda. ${ }^{4}$ Terkait hal ini,

${ }^{4}$ Berbagai pemikiran dituangkan menyikapi persoalan poligami, di antara artikel yang membahas poligami adalah Atik Wartini. "Poligami: dari Fiqh Hingga PerundangUndangan.” HUNAFA: Jurnal Studia Islamika 10, no. 2 (2013): h. 237-268. Leli Nurohmah. "Poligami Saatnya Melihat Realitas." Jurnal Perempuan 31 (2003): h. 31-45. Kristi Poerwandari. "Ilusi Poligami." Jurnal Perempuan Menimbang Poligami 31 (2003). Siti Hikmah. "Fakta Poligami Sebagai Bentuk Kekerasan Terhadap Perempuan.” Sawwa: Jurnal Studi Gender 7, no. 2 (2012): 1-20. Agus Sunaryo. "Poligami di Indonesia (Sebuah Analisis Normatif-Sosiologis)." Yin Yang 5, no. 1 (2010): h. 143-167. Anne Louis Dickson. "Pandangan Ibu-ibu 'Aisyiyah di Malang Terhadap Poligami." Fakultas Ilmu Sosial dan Ilmu Politik. Universitas Muhammadiyah. Malang (2007). Abdul Mustaqim. "Konsep Poligami Menurut Muhammad Syahrur." Jurnal Studi Ilmu al-Qur'an dan Hadis, vol. 8, 2007) (2007). Budi Rajab. "Meninjau Poligami; Perspektif Antropologis dan Keharusan Mengubahnya." Jurnal Perempuan 31 (2003): h. 67-84. Hamim Ilyas. "Poligami dalam Tradisi dan Ajaran Islam." Musawa: Jurnal Studi Gender dan Islam 1, no. 1 (2002): h. 19-26. Ertan Yilmaz, Lut Tamam, and Ufuk Bal. "Polygamy and its Effect on Mental Health/Poligami ve Ruh Sagligina Etkileri." Psikiyatride Guncel Yaklasimlar/Current Approaches to Psychiatry 7, no. 2 (2015): h. 221-229. Abdul Jalil. "Wanita dalam Poligami (Studi Pemikiran Muhammad Syahrur)." Jurnal Cendekia 2, no. 1 (2018). Lia Noviana. "Persoalan Praktik Poligami dalam Masyarakat Islam.” Jurnal Salam 15, no. 1 (2012). I. A. Sadnyini, and Jurnal Studi Jender Srikandi. "Poligami dan Kesengsaraan Perempuan." Jurnal Studi Jender Srikandi 6, no. 1 (2010). Ali Imron. "Menimbang Poligami dalam Hukum Perkawinan." Qistie Jurnal Ilmu Hukum 6, no. 1 (2012). Ahmad Khoirul Fata, and Mustofa Mustofa. "Menyoal Kontekstualisasi Hukum Islam Tentang Poligami.” Al-Ulum 13, no. 2 (2013): h. 415-434. Abdul Mustaqim. "Pemikiran Fikih Kontemporer Muhamad Syahrur Tentang Poligami dan Jilbab." Al-Manahij: Jurnal Kajian Hukum Islam 5, no. 1 (2011): h. 67-80. D Nasri. "Pespektif Orang Minang Terhadap Poligami dalam Novel Sitti Nurbaya." Jurnal Multilingual 1 (2010): h. 93-109. Ahmad Haries. "Poligami dalam Perspektif Ali Asghar Angineer dan Relevansinya dengan Konteks Indonesia Kekinian." Jurnal Mazabib 4, no. 2 (2007). Amrie Hakim. "Poligami, Masalah Krusial dalam Revisi Undang-Undang Perkawinan.” Jurnal Hukum Jentera Online 25 (2003). M Ending. "Poligami: Adilkah Kita?[Polygamy: Is it Fair for Us?]." Qawwam: Journal for Gender Mainstreaming 1, no. 1 (2006): 107Á11. Raihanah Abdullah. "Berpoligami: Antara Hak Suami dan Hak Isteri Menurut Undang-Undang Keluarga Islam di Malaysia.” Jurnal Syariah 11, no. 1 (2003): h. 131-146. Ema Khotimah. "Praktik Pernikahan Poligami pada Istri Ulama: Tinjauan Fenomenologis." Prosiding SNaPP: Sosial, Ekonomi dan Humaniora 1, 
penulis akan mengkaji poligami dalam konteks nas baik Alquran maupun hadis. Terkhusus teks dan konteks hadis, penulis mentakhrij hadis terkait poligami.

\section{Poligami dalam Teks Hadis}

Mengenai poligami ada beberapa hadis yang bisa dijadikan sebagai sumber rujukan, ${ }^{5}$ akan tetapi di sini akan dibahas hadis yang hanya dari kasus Qais bin al-Harits. Pertama, hadis yang diriwayatkan oleh Sunan Abû Dawud dalam Bab Fî̀ Man Aslama Wa 'Indahu Nisâun Aktsara Min Arba (Au Uhktahin), yang berbunyi: ${ }^{6}$

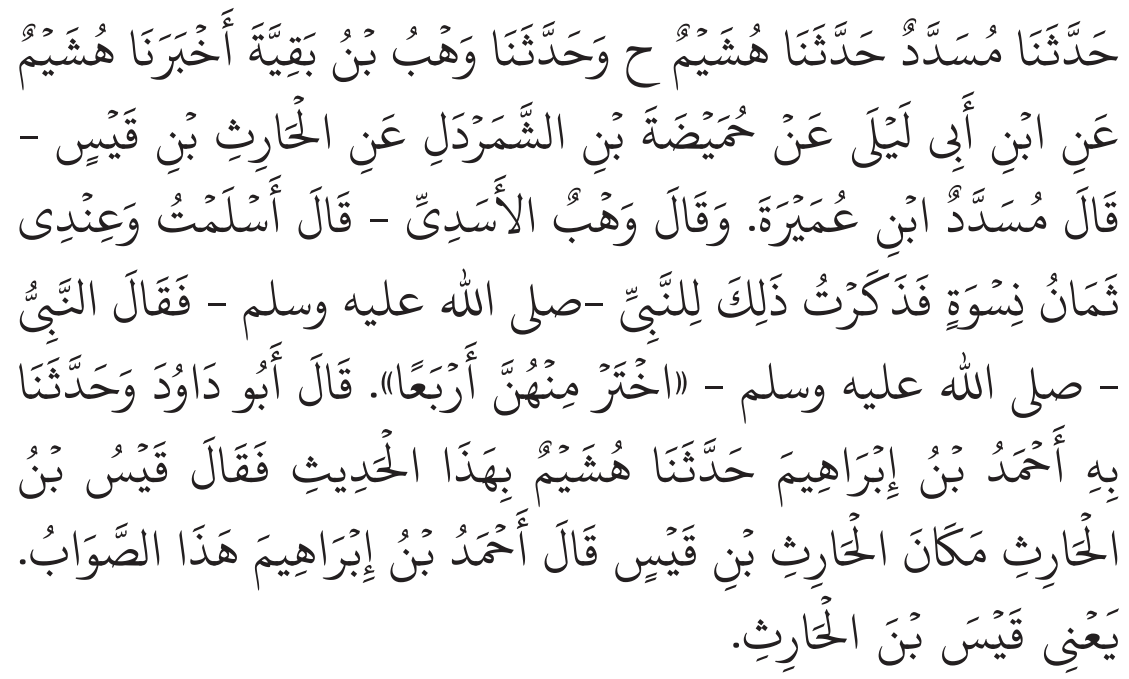

no. 1 (2017): h. 93-120. Yuli Pitriana, Emi Zulaifah. "Pengetahuan Poligami dalam Islam dan Sikap Terhadap Poligami pada Wanita Muslim." Psikologika: Jurnal Pemikiran dan Penelitian Psikologi 10, no. 20 (2005).

${ }^{5}$ Hal ini seperti kasus masuk Islamnya Ghailan bin Salamah yang memiliki sepuluh istri, kemudian Rasulullah bersabda, "Khudz Minhunna Arba'an". Hadis ini diriwayatkan oleh al-Turmudzi dalam Kitab an-Nikah Bab Ma Ja’a Fi al-Rajul Yuslimu Waindahu Asyra Niswah, hadis yang ke 2721. Imam Ahmad juga meriwayatkan didalam Musnad-nya. Lihat Ibnu Majah, Sunan Ibnu Majah, 1 (Bayrut: Dar al-Fikr, 2004), h. 612.

${ }^{6}$ Abû Dawud Sulaiman bin Al-Atsast Al-Sajastani, Sunan Abî Dawud, 2, Hadis No 2241 (Bayrut: Dar al-Fikr, 2003), h. 248. 
Bila diskemakan hadis tersebut sebagai berikut:

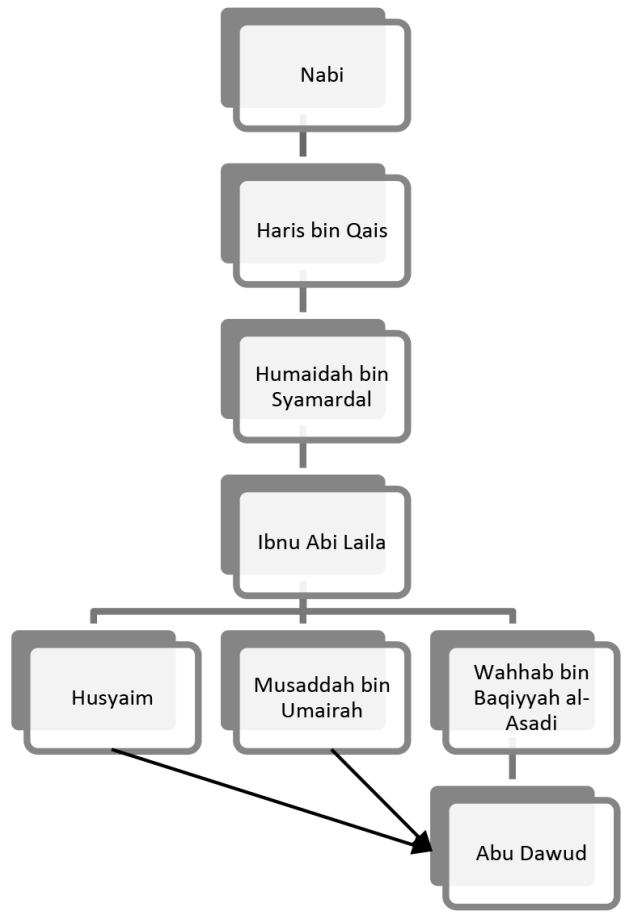

Untuk mengetahui kualitas hadis tersebut, maka penulis akan mendeskripsikan masing-masing sanad yang tertera dalam hadis tersebut.

Abu Dawud nama sebenarnya adalah Sulaiman bin al-Asyast bin Saddad bin Amr bin Amir (Imran). Ibnu Dasah dan al-Ajiri menyatakan bahwa nama ia adalah Sulaiman bin al-Asy'ast bin Ishaq bin Basyir bin Syaddad. Ia biasanya meriwayatkan hadis diantaranya dari jalur Abi Salmah al-Tabudzaky, Abû Walid al-Thayalisi, Muhammad bin Katsir al-Abadi, Muslim bin Ibrahim, Abû Amr al-Audi, Abû Taubah al-Halabi. Sementara jalur yang mengambil periwatan dari Abû Dawud (anhu) di antaranya adalah Abû Ali Muhammad bin Ahmad bin Amr al-Lu'lu'i, Abû al-Thayyib Ahmad bin Ibrahim bin Abdul Rahman al-Asynani, Abu Amr bin Ahmad bin Ali bin al-Hasan al-Basyari dan Abu Sa'id Ahmad bin Muhammad bin Ziad al-A'rabi. ${ }^{7}$

${ }^{7}$ Syihabuddin Ahmad Bin Ali Bin Hajar Al-Asqalani, Tahdzîb Al-Tahdzîb (Bayrut: Dar al-Fikr, 1995). Dimuraja’ah oleh Sidqi Jamil Al-'Athar, Tahdzîb Al-Tahdzîb, 3 (Bayrut: Dar alFikr, 1995), h. 458. 
Mengenai kepribadiannya, Ahmad bin Muhammad bin Yasin alHarwi menyatakan bahwa Abu Dawud adalah salah seorang hafidz(huffadz al-Islam) untuk masalah hadis dan ilmu hadis, dan jalur sanadnya dalam posisi derajat yang paling tinggi, orang yang menjaga kehormatan diri (affaf), baik, dan wara'. Abû Mûsa bin Haris menyatakan bahwa diciptakan Abû Dawud di dunia untuk hadis, dan di akhirat untuk surga. Al-Hâkim menyatakan bahwa Abû Dawud adalah Imam ahli hadis di masanya tanpa pertentangan. Ibnu Hajar al-Asqalani menulis dalam kitabnya Tahdzîb at-Tahdîzb mengutip pendapat Mûsa bin Harun yang menyatakan bahwa ia (Mûsa bin Harun) tidaklah melihat seseorang yang lebih utama (afdal) dibanding Abû Dawud. Dan ia (Mûsa bin Harun) memerintahkan Aḥmad Muhammad bin Yahyâ bin Abî Saminah untuk menuliskan hadis yang datang dari Abû Dawud. Sementara Muslimah bin Qasim menyatakan bahwa Abû Dawud adalah siqqah, zahid (ahli zuhud), mengetahui tentang hadis ('arifan bi al-hadîs), seorang imam pada masanya. ${ }^{8}$

Husyaim nama sebenarnya adalah Husyaim bin Basyir bin al-Qâsim bin Dinar al-Sulami, Abû Muawiyyah bin Abî Khozim al-Wasithi. Biasanya ia meriwayatkan hadis di antaranya dari jalur bapaknya, saudara kakak Bapaknya yakni al-Qâsim bin Mahran, Abdul Muluk bin Umair, dan Ya'lâ bin 'Atha. Sementara yang meriwayatkan hadis darinya, di antaranya adalah Mâlik bin Anas, Syu'bah, al-Tsauri, anaknya yakni Sa'îd, dan Ibn al-Mubârak. ${ }^{9}$ Mengenai kepribadiannya, Aḥmad bin Sinan dari Ibn Mahdi menyatakan bahwa, menurutnya, hafalan Husyaim itu lebih kuat dari pada hafalan Abî 'Awânah, sementara tulisan Abî 'Awânah lebih kuat daripada hafalan Husyaim. Al'Ajali menyatakan Husyaim adalah seorang yang moderat lagi tsiqqah. Ibn Abî Hatim menyatakan bahwa bapaknya pernah ditanya tentang Husyaim dan Yazid bin Harun, maka bapaknya berkata bahwa Husyaim adalah lebih hafal dibanding Yazid bin Harun. Maka aku (Ibn Abî Hatim) bertanya kepada bapaknya tentang Husyaim, maka bapaknya menjawab bahwa ia adalah seorang yang tsiqqah, dan ia

${ }^{8}$ Syihabuddin Ahmad bin Ali bin Hajar Al-Asqalani, Tahdzib Al-Tahdzib. Dimuraja'ah Oleh Sidqi Jamil Al-'Athar, Tahdzib Al-Tahdzib, h. 459.

${ }^{9}$ Sidqi Jamil Al-'Athar, Tahdzib Al-Tahdzib, 4: h. 66. 
juga seorang yang lebih hafal dibanding Abî 'Awânah. Ia berkata, bahwa Abû Zar'ah bertanya tentang Husyaim dan Jarîr, ia pun menjawab bahwa Husyaim adalah orang yang lebih hafal dibanding Husyaim dan Jarîr.

Ibn Sa'ad menyatakan bahwa Husyaim adalah tsiqqah, banyak hadisnya. Al-Harabi menyatakan bahwa Husyaim meriwayatkan hadishadis dengan makna. Yazid bin Harun menyatakan bahwa, "Tidaklah aku melihat orang yang paling hafal hadisnya dari pada Husyaim kecuali alTsuari”. Al-Husain bin al-Hasan al-Rumi, ia menyatakan, "Tidaklah aku melihat seseorang yang paling banyak zikirnya kepada Allah Swt. selain Husyaim". Ibnu Hibban menyebut Husyaim dalam kitabnya al-Tsiqqat. ${ }^{10}$

Musaddad nama lengkapnya adalah Musaddad Musarhal bin Musalbal bin Mustaurid al-Asadi, al-Bashari, atau panggilan lainnya adalah Abû al-Hasan. Ia adalah seorang yang tsiqqat lagi hâfidz. Ada yang menyatakan bahwa ia adalah seorang yang pertama menulis kitab al-Musnad di Bashrah, ia meninggal pada tahun $28 \mathrm{H}$. Dikatakan pula nama ia adalah Abdul Muluk bin Abdul Aziz. Nama Musaddad adalah nama laqab-nya. ${ }^{11}$

Jalur periwayatan hadis, biasanya dia meriwayatkan dari Abdullah bin Yahya bin Abî Katsir, Husyaim, Yazid bin Zari', Isâ bin Yûnus Fudail bin Iyad, Mahdi bin Maimun, Juwairiyyah bin Asma, Ja'far bin Sulaiman, Hammad bin Yazid, Abî al-Ahwash, dan lainnya. Sementara yang mengambil periwayatan darinya adalah al-Bukhâri, Abû Dawud, alTurmudzî, al-Nasâi dengan perantaraan Muhammad bin Muhammad bin Khilad al-Bahili, Aḥmad bin Muhammad bin Madwiyyah, Muhammad bin Sa'id al-Dandani, dan lainnya. ${ }^{12}$

Mengenai kepribadiannya, Abû Zar'ah berkata, bahwa Aḥmad bin Hanbal berkata kepadanya bahwa Musaddad adalah shadûq. Za'far bin Abî Usman berkata, "Aku berkata pada Ibn Mu'ayyan tentang siapa yang paling banyak menulis di Bashrah? Maka ia menjawab, "Saya menulis

${ }^{10}$ Sidqi Jamil Al-'Athar, Tahdzib Al-Tahdzib, 4:68-69.

${ }^{11}$ Lihat Syihabuddin Ahmad bin Ali bin Hajar Al-Asqalani, Tahdzib Al-Tahdzib. Dimuraja'ah oleh Sidqi Jamil Al-Athar, Tahdzib Al-Tahdzib, 2:579.

12 Syihabuddin Ahmad bin Ali bin Hajar Al-Asqalani, Tahdzib Al-Tahdzib. Dimuraja'ah oleh Sidqi Jamil Al-'Athar, Tahdzib Al-Tahdzib, 8:130. 
hadis dari Musaddad, karena dia adalah tsiqqah, tsiqqah". Muhammad bin Harun al-Fallas dari Ibn Mu'ayyan menyatakan bahwa ia adalah shadûq. Al-Nasa'î menyatakan bahwa ia adalah tsiqqah. Al-Ajali menyatakan bahwa Musaddad Musarhal bin Musalbal bin Mustaurid al-Asadi adalah tsiqqah. Ibnu Abî Hâtim dari bapaknya menyatakan bahwa Musaddad adalah tsiqqah. Al-Bukhâri menyatakan bahwa Musaddad meninggal pada tahun 228 H. Ibnu Hajar menyatakan mengutip pendapat Ibn Qani’ bahwa Musaddad adalah tsiqqah. Ibnu Adi juga menyatakan bahwa Musaddad adalah orang yang paling pertama menyusun al-Musnad di Bashrah. Ibnu Hibban menyebutnya dalam kitab al-Tsiqqat, sementara dalam tarîkh al-musajja nama Musaddad adalah Abdul Muluk bin Abdul Aziz. ${ }^{13}$

Wahhab bin Baqiyyah bin Usman bin Syabur bin 'Ubaid bin Adam bin Ziad al-Wasithî, disebut juga Abû Muhammad atau juga Wahban. Ia adalah tsiqqat, meninggal pada tahun $39 \mathrm{H}$ pada usia 95/96 tahun. ${ }^{14}$ Jalur periwayatannya biasanya ia meriwayatkan hadis dari jalur Hammad bin Zaid, Ja’far bin Sulaiman al-Dhob'î, Husyaim, Salim bin Ahdhar, Abdul A'lâ bin Abdul A'lâ, Khâlid bin 'Abdullah, 'Umar bin Yûnus al-Yamani, Abî Mu’awiyah, dan lainnya. Sementara yang meriwayatkan hadis darinya adalah Muslim, Abû Dawud, al-Nasầ biasanya meriwayatkannya melalui jalur Zakaria al-Sajri yang diambil dari jalur Wahhab bin Baqiyyah, Abû Zar'ah al-Razi, Ibn Abî Ashim, Hanbal bin Ishâq, Abû al-Qâsim alBaghâwi, dan lainnya. Mengenai kepribadiannya, Hâsyim bin Murtsad dari Ibn Mu'ayyan menyatakan bahwa Wahban adalah tsiqqah. Al-Khâtib menyatakan bahwa Wahhab bin Baqiyyah adalah tsiqqah. Ibn Hibbân menyebutnya dalam kita al-Tsiqqat. Ibn Hajar menyatakan mengutip pendapat Muslimah bahwa Wahhab bin Baqiyyah adalah tsiqqah. Wahhab bin Baqiyyah menurut Bahsyal dilahirkan pada tahun $155 \mathrm{H}$ dan meninggal pada tahun $239 \mathrm{H}^{15}$

Ibnu Abî Laila nama lengkapnya adalah Abdul Rahman bin Abî Laila. Namanya adalah Yasar, dan dikatakan pula Bilâl, selain itu dikatakan pula Dawud bin Bilâl bin Bulail bin Uhaiyhah bin al-Julah bin al-Harisy

\footnotetext{
${ }^{13}$ Sidqi Jamil Al-'Athar, Tahdzib Al-Tahdzib, 8 : h. 131.

${ }^{14}$ Lihat Syihabuddin Ahmad bin Ali bin Hajar Al-Asqalani, Tahdzib Al-Tahdzib, h. 651.

${ }^{15}$ Lihat Syihabuddin Ahmad bin Ali bin Hajar Al-Asqalani, 9 : h. 176.
} 
bin Jahjaba bin Kulfah bin 'Auf bin 'Amr bin 'Auf bin Mâlik bin 'Aus al-Anshâri al-Ausi, Abû Isâ al-Kûfî, orang tuanya bernama Muhammad. Biasanya jalur periwayatan hadisnya di antaranya adalah jalur dari bapaknya, 'Umar, 'Usman, 'Alî, Sa'ad, Hudzaifah, Mu'adz bin Jabal, al-Miqdad, Ibn Mas'ûd, Abû Dzar, Ubay bin Ka’ab, Bilâl bin Rabah, Ibn 'Umar, dan lainnya. Sementara jalur periwayatan hadis dari dirinya adalah anaknya yaitu Isâ, cucunya Abdullah bin Isâ, 'Amr bin Maimun al-'Audi, Abdul Muluk bin Umair, dan lainnya.

Mengenai kepribadiannya, Ishâq bin Manshûr dari Ibn Mu'ayyan, bahwa Ibn Abî Laila adalah tsiqqah. Al-Ajali berkata bahwa ia adalah orang Kuffah dan dari kalangan Tabi'in. ${ }^{16}$

Humaidah bin al-Syamardal al-Asadi al-Kûfi adalah maqbûl (diterima), terhimpun dalam Ibn Mâjah, ia disebut juga dengan nama Humaidah binti al-Syamardal. ${ }^{17}$ Biasanya ia meriwayatkan hadis dari Qais bin alHâris. Sementara yang meriwayatkan jalur hadis dari dirinya adalah Muhammad bin Abdul Rahman bin Abî Laila, Sulaiman al-Syaibâni, Muhammad bin al-Saib al-Kalabi, dan lainnya. Mengenai kepribadiannya, Ibn 'Adi dalam kitabnya al-Kâmil menyatakan bahwa tidaklah ia memiliki hadis kecuali dua atau tiga hadis. Ibn Hibban menyebut namanya dalam kitab al-Tsiqqat. Nama Humaidah bin al-Syamardal termaktub dalam kitab Sunan Ibn Majah. Ibn Hajar al-Asqalani menyatakan, mengutip pendapat Ibn al-Qattan, bahwa tidak diketahui keadaannya. Ibn al-Sakan mendha'̂̀fkan hadisnya. Al-Bukhâri menyatakan dengan istilah fîhi nadzar. Sementara al-Aqili dan Ibn al-Jarud menyebutnya bagian dari al-dhu'afâ. ${ }^{18}$

Qais bin al-Haris bin Jidar bin al-Asadi, dikatakan pula al-Haris bin Qais bin al-Aswad, atau dikatakan pula Ibn Amirah, ia adalah kakeknya Qais bin al-Rabi. Jalur periwayatan hadisnya biasa dari Humaidah bin al-Syamardal dalam hadis aslamtu wa indi tsamanu niswatin fadazakartu dzalika li an-nabiyyi shallalahu 'alaihi wasallam faqala: "Ikhtar minhunna arba'an". Ibn Hajar menyatakan mengambil pendapat al-Baihaqi yang men-râjih riwayat seseorang yang berkata kepada al-Haris bin Qais. Dan

\footnotetext{
${ }^{16}$ Syihabuddin Ahmad bin Ali bin Hajar Al-Asqalani, 5 : h. 166.

${ }^{17}$ Lihat Syihabuddin Ahmad bin Ali bin Hajar Al-Asqalani, 1 : h. 144.

${ }^{18}$ Lihat Syihabuddin Ahmad bin Ali bin Hajar Al-Asqalani, 2 : h. 469.
} 
di dalam Tarjamah, Qais bin al-Rabi' dari jalur Ibn Sa’ad berkata, bahwa ia adalah termasuk anak dari al-Hâris bin Qais yang masuk Islam dan mempunyai delapan isteri, dan ini adalah hadis yang dikeluarkan oleh Abû Dawud dan Ibn Majah. ${ }^{19}$

Dari pemaparan kepribadian dan kualitas personal periwayatan dari jalur sanad yang telah dijelaskan di atas tidak ada yang memiliki cacat, dan semuanya dianggap tsiqqah.

Sementara dari hadis yang kedua, yakni periwayatan dari jalur Ibnu Majah dalam Bab al-Rajul Yuslimu Wa 'Indahu Aktsar Min 'Arba' Niswatin, yang berbunyi: ${ }^{20}$

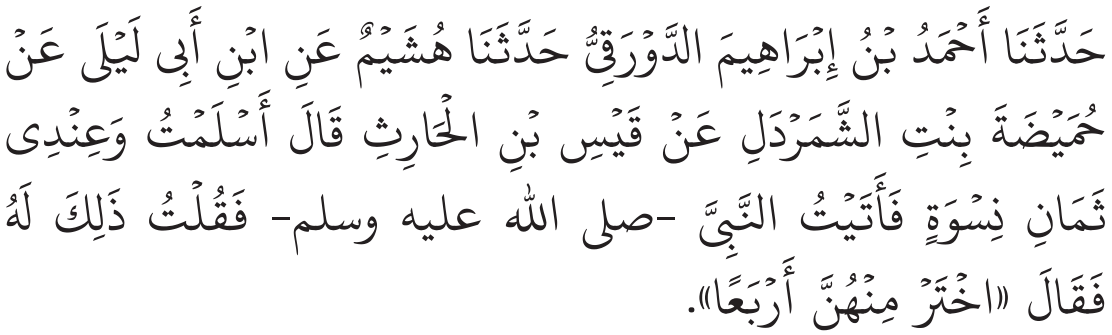

Jalur periwayatan hadis tersebut bila diskemakan sebagai berikut:

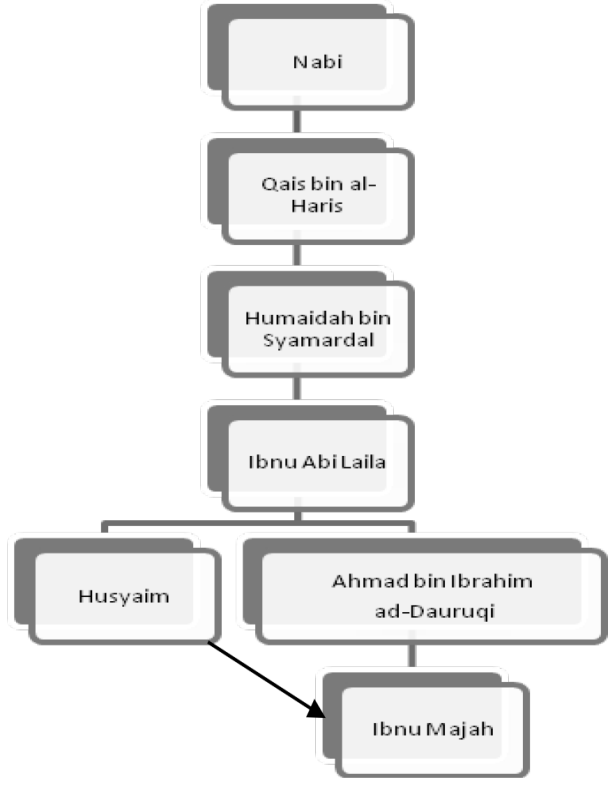

${ }^{19}$ Syihabuddin Ahmad bin Ali bin Hajar Al-Asqalani, 6 : h. 522.

${ }^{20}$ Ibnu Majah, Sunan Ibnu Majah, 1 : h. 612. 
Untuk mengetahui kualitas hadis tersebut, maka penulis akan mendeskripsikan masing-masing sanad yang tertera dalam hadis tersebut.

Ibn Majah nama sebenarnya adalah Muhammad bin Yazîd al-Raba'î, Abû Abdillah bin Mâjah al-Qazwuini al-Hâfidz. Jalur periwayatan dari Ibn Majah adalah Alî bin Sâîd bin Abdillah al-Ghadani, Ibrahim bin Dinar al-Jarsyi al-Hamdani, Abû al-Thayyib Ahmad bin Ruh al-Masy'arani, Ishâq bin Muhammad al-Qazwuini, dan lainnya. ${ }^{21}$

Ibn Hajar al-Asqalani menyatakan kumpulan hadis Ibn Majah dalam kitabnya bagus, terdapat pula di dalam hadisnya yang lemah sekali, sehingga menurut Ibn Hajar, bahwa sampailah al-Sara berkata, "Kadang kala khabar yang sendirian dalam hadisnya sering lemah..... bila dijumlahkan maka terdapat dalam hadisnya terdapat hadis yang munkar”. Ibn Hajar juga menyatakan bahwa ia mendengar al-Hâfidz Abal Hujjâj al-Mâzi berkata, "Setiap apa yang sendirian dari Ibn Majah maka ia adalah lemah, dalam artian hadis yang terdapat dalam kitabnya dan tidak terdapat dalam kitab imam yang lima, maka hadis tersebut biasanya lemah". ${ }^{22}$

Aḥmad bin Ibrâhim bin Katsir bin Zaid al-Dauraqi al-Nukri alBagdâdi, disebut juga dengan nama Abû 'Abdillah. Ia adalah tsiqqah, meninggal pada tahun $46 \mathrm{H} .{ }^{23}$ Ia biasanya meriwatkan hadis di antaranya dari Hafs bin Ghayyats, Jarîr, Hâsyim, Mubasyir bin Ismâil al-Halabi dan Khâlid bin Mukhalid. Sementara yang mengambil periwayatan dari Aḥmad bin Ibrâhim di antaranya adalah Imâm Muslim, Abû Dawud, al-Turmudzî, Ibn Majah, dan Hanbal. Mengenai kepribadiannya, Abû Hâtim menyatakan bahwa ia adalah shadûq. Shâlih Jazrah menyatakan bahwa Ahmad bin Ibrâhim adalah seorang yang paling banyak hadisnya, paling mengetahui tentang hadis, ia adalah tsiqqah. Ibn Hajar al-Asqalani dalam kitabnya Tahdzîb at-Tahdîzb, mengambil pendapat al-Aqili, bahwa ia adalah tsiqqah. Al-Khalilî dalam kitabnya al-Irsyâd, menyatakan bahwa ia adalah tsiqqah muttafaq 'alaih, Ibn Hibbân juga menyebutkan nama

\footnotetext{
${ }^{21}$ Syihabuddin Ahmad bin Ali bin Hajar Al-Asqalani, Tahdzib Al-Tahdzib, 7 : h. 498.

${ }^{22}$ Lihat Syihabuddin Ahmad bin Ali bin Hajar Al-Asqalani, Tahdzib Al-Tahdzib, 7 : h. 499.

${ }^{23}$ Lihat Syihabuddin Ahmad bin Ali bin Hajar Al-Asqalani, 1 : h. 11.
} 
Aḥmad bin Ibrâhim dalam kitabnya al-Tsiqqat. ${ }^{24}$

Sementara untuk nama Husyaim, Ibn 'Ali Laila, Humaidah bin Syamardal dan Qais bin al-Harits, telah dijelaskan di atas. Jadi, hadis ini juga bernilai baik, karena semuanya tidak mempunyai cacat.

\section{Poligami dalam Konteks Nas Alquran dan Hadis}

Secara historis-sosiologis, berabad-abad sebelum Islam diwahyukan, masyarakat di berbagai belahan dunia telah mengenal dan mempraktikkan poligami. ${ }^{25}$ Pada masyarakat Mesir kuno misalnya, dalam catatan sejarah bahwa praktik poligami dianggap hal yang wajar asalkan calon suami mau berjanji akan membayar uang yang banyak kepada isteri pertama apabila nanti suami menginginkan untuk menikah lagi. Di berbagai bangsa Timur kuno seperti Siria, Babylonia dan Madyan memiliki anggapan bahwa praktik poligami merupakan hal yang suci karena orang-orang yang mereka anggap suci (raja-raja) melakukan poligami. Di Cina pun demikian, seorang laki-laki berhak mengawini seorang atau beberapa

${ }^{24}$ Syihabuddin Ahmad bin Ali bin Hajar Al-Asqalani, 1: h. 42.

${ }^{25}$ Istilah poligami telah dikenal dalam masyarakat pra Islam. Selain poligami, ada beberapa istilah perkawinan yang telah mentradisi. Pertama, perkawinan al-istibda, yaitu seorang suami yang meminta istrinya apabila sudah suci dari haidhnya untuk melayani seseorang yangterkenal dengan kemuliaan, keberanian, dan kecerdasannya. Tujuannya untuk memperoleh keturunan yang memiliki sifat laki-laki tersebut. Kedua, perkawinan al-rahthun, seorang wanita yng digauli beberapa laki-laki, apabila wanita tersebut telah hamil dan melahirkan, maka wanita itu memanggil seluruh laki-laki yang menggaulinya. Kemudian ia menunjuk salah satu dari laki-laki tersebut untuk dijadikan nasab ayah untuk anaknya dan tidak ada lagi bagi laki-laki tersebut untuk menolaknya. Ketiga, perkawinan maqthu', seorang anak laki-laki mengawini ibu tirinya setelah ayahnya meninggal dunia. Keempat, perkawinan badal, yaitu dua orang suami saling tukar menukar isteri mereka tanpa cerai, dengan tujuan untuk memuaskan libido seksual mereka dan untuk menghindari dari kebosenan. Kelima, perkawinan shighar, seseorang yang mengawinkan anak peempuannya atau saudara perempuannya dengan tanpa mahar atau berlaku sebaliknya. Keenam, perkawinan baghaya, jenis perkawinan ini hampir sama dengan perkawinan al-rathun, yang membedakan dalam perkawinan baghaya ini wanita (pelacur) tersebut menisbatkana anaknya kepada laki-laki yang paling mirip wajahnya dengan anaknya tersebut. Ketujuh, perkawinan alirts, seorang isteri yang ditinggal mati oleh suaminya dan yang tidak memiliki anak laki-laki, ia menjadi warisan kerabat suaminya. Kedelapan, perkawinan mutah, yaitu perkawinan yang bersifat sementara dengan cara menentukan kurun waktu pernikahan dan bayarannya. Kesembilan, perkawinan akhdan, perkawianan kongsi, jika wanita itu banyak yang menyukai, maka lakilaki yang menggemarinya itu dapat berkongsi untuk menjadikannya isteri bersama. Kesepuluh, perkawinan sewa/gadai, yakni seseorang menggadaikan anak gadisnya dalam jangka waktu tertentu dengan sejumlah uang sewa. Lihat Haikal, Rahasia Perkawinan Rasulullah SAW (Jakarta: Rajawali Press, t.t.), h. 14. 
orang wanita jika isteri yang pertama tidak bisa memberinya keturunan, tetapi dalam kasus ini isteri pertama menjadi ratu dari para isteri yang lain. India pun demikian, praktik poligami terjadi di kalangan kerajaan dan konglomerat, biasanya motif berpoligami karena isteri pertama tidak memiliki keturunan atau emosional. Artinya, mengutip istilah Musfir Husain al-Jahrani, praktik poligami merupakan budaya yang melekat sepanjang peradaban umat manusia, baik yang terjadi di kalangan masyarakat yang berperadaban tinggi maupun rendah. ${ }^{26}$

Bila merujuk kitab Taurat dijelaskan bahwa Nabi Sulaiman memiliki 1000 orang isteri, 700 orang isteri dari golongan merdeka dan 300 orang dari golongan budak. Nabi Daud demikian, memiliki 100 isteri. Nabi Ibrahim pun melaksanakan poligami, memiliki dua isteri yakni Sarah dan Hajar. ${ }^{27}$

Pada masyarakat Arab pra-Islam, praktik poligami telah menjadi sebuah kebiasaan, ${ }^{28}$ seorang laki-laki berhak menikahi sejumlah wanita yang dikehendaki tanpa ikatan maupun syarat apapun. Bisa dikatakan bahwa tirani dan dominasi serta perbudakan kaum pria terhadap kaum perempuan menjadi salah satu penyebab poligami pada saat itu. Adanya sistem patriarkhi, yaitu kaum pria menempati kedudukan mendominasi dan mendaulati kaum perempuan. Setelah Islam datang, poligami tidak serta merta dihapuskan, namun Nabi melakukan perubahan sesuai dengan surat al-Nisâ [4] ayat 3, yaitu dengan membatasi jumlah bilangan isteri sampai dengan empat orang (limited polygamy) dan menetapkan syarat yang ketat, yaitu harus mampu berlaku adil. ${ }^{29}$ Setelah turunnya ayat ini, yakni Q.s. Al-Nisa' [4]: 3.

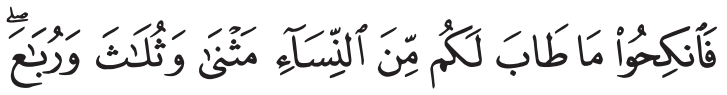

Nabi segera memerintahkan semua laki-laki yang memiliki isteri lebih dari empat agar menceraikan istri-istrinya sehingga setiap suami

${ }^{26}$ Musfir Husain al-Jahrani, Poligami dari Berbagai Persepsi, trans. oleh Muh. Suten Ritonga (Jakarta: Gema Insani Press, 2002), h. 35.

${ }^{27}$ Untuk lebih lengkapnya mengenai pernikahan poligami para nabi bisa dilihat dalam Ahmad Abdul Wahhab, Ta'addud Nisa al-Anbiya; wa Makanah al-Mar'ah fi al-Yahudiyah wa al-Masiyah wa al-Islam (Kairo: Maktabah Wahbah, 1989).

${ }^{28}$ Untuk lebih lengkapnya bisa dilihat dalam Abdullah Nasih 'Ulwan, Ta'addud Zaujat fi al-Islam, cet. IX (Kairo: Dar as-Salam, 2006), 11. Lihat pula Kiram Fahmi Farhat, Tảaddud al-Zaujat fi al-Adyan (Kairo: Dar al-Aaq al-Arabiyah, 1971).

${ }^{29}$ Murtadha Muthahari, Hak-hak Wanita dalam Islam (Jakarta: Lentera, 2001). 
maksimal hanya boleh punya empat isteri. ${ }^{30} \mathrm{Hal}$ ini seperti yang terjadi pada Naufal ibn Muawiyah, ia berkata: "Ketika aku masuk Islam, aku memiliki lima orang isteri. Rasulullah berkata: "Ceraikanlah yang satu dan pertahankan yang empat.

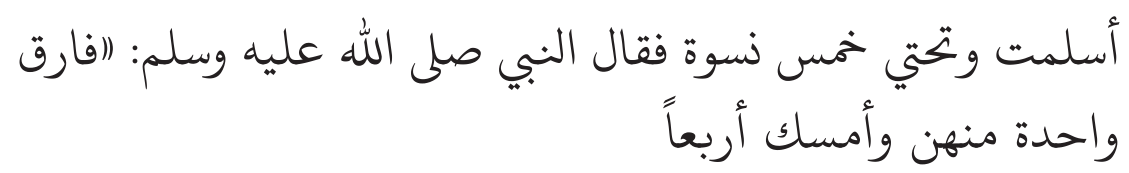

Pada riwayat lain, Qais ibn Tsabit berkata: "Ketika masuk Islam aku punya delapan isteri. Aku menyampaikan hal itu kepada Rasul dan beliau berkata: "pilih dari mereka empat orang."

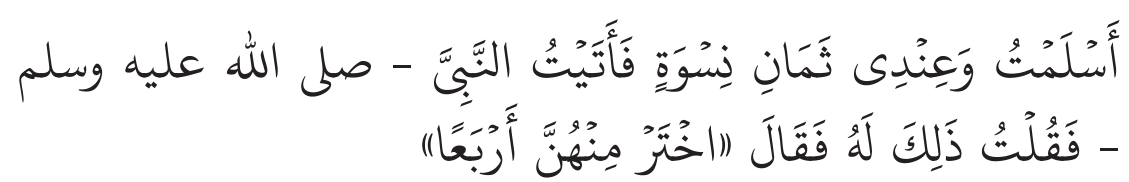

Riwayat serupa dari Ghailan ibn Salamah Al-Tsaqafi menjelaskan bahwa dirinya punya sepuluh orang isteri, lalu Rasul bersabda: "pilih empat orang dan ceraikan yang lainnya."

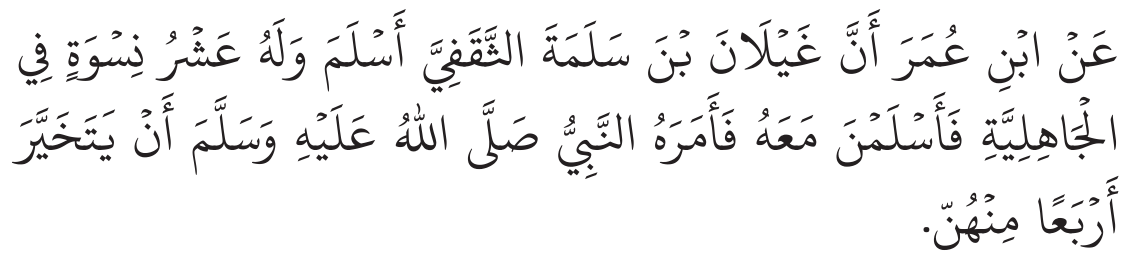

Dengan demikian bisa dikatakan bahwa masyarakat muslim pada awalnya mempraktikkan poligami lebih karena pengaruh sosial dan budaya yang berlaku pada masa itu. Ketika beberapa sahabat Nabi berpoligami, tidak lain ialah karena faktor budaya pada saat itu yang memandang lumrah terhadap poligami, bahkan membanggakannya. Pada saat itu, monogami menjadi hal di luar kebiasaan, hanya sedikit orang yang melakukannya. ${ }^{31}$

${ }^{30}$ Surat al-Nisa ayat 3 tersebut kemudian menjadi bahan kajian bagi ulama dan akademisi dalam menafsirkan ayat tersebut. Di antara kajian yang telah terpublikasi di antaranya Abd. Moqsith, “Tafsir Atas Poligami dalam Al-Qur’an”, Karsa 23, No. 1 (Juni 2015): h. 133-149. Nurus Sa’adah, Vita Fitria, Kurnia Widiastuti, "Poligami dalam Lintas Budaya dan Agama: Meta-Interpretation Approach", Asy-Syir'ah Jurnal Ilmu Syariah dan Hukum 49, No. 2, (Desember 2015): h. 479-499.

${ }^{31}$ Lia Noviana, Persoalan Praktik Poligami dalam Masyarakat Islam (UIN Maulana Malik Ibrahim, t.t.), h. 87. 
Berdasarkan catatan sejarah dalam konteks turunnya hadis dan Alquran, selain dari nabi memerintahkan hanya mengambil empat isteri saja, bahwa Urwah bin Zubair r.a. bertanya kepada 'Aisyah tentang ayat Q.s. al-Nisâ' [4] ayat 3. Maka 'Aisyah menjawab, 'Wahai anak saudara perempuanku, yatim di sini maksudnya anak perempuan yang ada di bawah asuhan walinya yang hartanya bercampur dengan harta walinya, dan harta serta kecantikan yatim itu membuat pengasuh anak yatim itu senang kepadanya lalu ingin menjadikan perempuan yatim itu sebagai isterinya. Tapi pengasuh itu tidak mau memberikan mahar (maskawin) kepadanya dengan adil, yakni memberikan mahar yang sama dengan yang diberikan kepada perempuan lain. Karena itu pengasuh anak yatim seperti ini dilarang mengawini anak-anak yatim itu kecuali kalau mau berlaku adil kepada mereka dan memberikan mahar kepada mereka lebih tinggi dari biasanya. Dan kalau tidak dapat berbuat demikian, maka mereka diperintahkan kawin dengan perempuan-perempuan lain yang disenangi." (H.r. Al-Bukhâri, Abû Dawud, al-Nasâ'i, dan al-Turmudzi). ${ }^{32}$

Sepintas lalu jika memperhatikan hadits di atas, memang itu seolaholah ijtihad dari 'Aisyah sendiri, namun jika diperhatikan maka akan ditemukan bahwa pendapat 'Aisyah tersebut lebih banyak benarnya, karena ia termasuk yang mengetahui maksud ayat dari surat al-Nisa' [4]: 3, jadi dia termasuk bagian dari sejarah yang mengetahui sebabsebab turunnya ayat tersebut. Pendapat ini sesuai dengan maksud ayat tersebut. Jadi dalam hal ini berdasarkan ayat di atas, bagi laki-laki yang terpikat oleh janda kaya yang memiliki anak, di mana anaknya itu ada memiliki harta, maka laki-laki tersebut tidak boleh menikahinya dengan maksud akan mengurus hartanya apalagi sampai mencampurkan harta mereka dengan hartanya. ${ }^{33}$

Sebab, ayat ini diturunkan di Madinah setelah perang Uhud. Sebagaimana dimaklumi, karena kecerobohan dan ketidakdisiplinan kaum Muslim dalam perang itu mengakibatkan mereka kalah telak. Banyak prajurit Muslim yang gugur di medan perang. Dampak selanjutnya,

32 Sayyid Sabiq, Fiqh Sunnah, vol. VI (Bandung: al-Ma’rif, 1990), h. 136-37.

${ }^{33}$ Rafid Abbas, "Poligami dalam Kajian Nash Al-Qur'an dan Hadis," Edu-Islamika 3, no. 1 (Maret 2012): h. 144. 
jumlah janda dan anak-anak yatim dalam komunitas Muslim meningkat drastis. Tanggung jawab pemeliharaan anak-anak yatim itu tentu saja kemudian dilimpahkan kepada para walinya. Tidak semua anak yatim berada dalam kondisi papa dan miskin, di antara mereka ada yang mewarisi harta yang banyak, peninggalan mendiang orang tua mereka. ${ }^{34}$

Pada situasi dan kondisi yang disebutkan terakhir, muncul niat jahat di hati sebagian wali yang memelihara anak yatim. Dengan berbagai cara mereka berbuat culas dan curang terhadap anak yatim tersebut. Terhadap anak yatim yang kebetulan memiliki wajah yang cantik, para wali itu mengawini mereka, dan jika tidak cantik, mereka menghalanginya agar tidak menikah meskipun ada laki-laki lain yang melamarnya.

Tujuan para wali menikahi anak yatim yang berada dalam kekuasaan mereka semata-mata agar harta anak yatim itu tidak beralih pada orang lain, melainkan jatuh ke dalam genggaman mereka sendiri, sehingga akibatnya tujuan luhur perkawinan tidak terwujud. Tidak sedikit anak yatim yang telah dinikahi oleh para wali mereka sendiri mengalami kesengsaraan akibat perlakuan tidak adil. Anak-anak yatim itu dikawini, tetapi hak-hak mereka sebagai isteri, seperti mahar dan nafkah tidak diberikan. Bahkan, harta mereka dirampas oleh suami mereka sendiri untuk menafkahi isteri-isteri mereka yang lain yang jumlahnya lebih dari batas kewajaran. ${ }^{35}$

Pendapat kedua mengatakan bahwa ayat ini ditujukan kepada lakilaki pada zaman jahiliyah yang menikahi perempuan lebih dari empat orang. Dan menafkahinya dengan semua hartanya hingga ia menjadi miskin. Dan ia menikahi anak yatim dengan maksud mengambil hartanya untuk menafkahi isteri-isterinya yang lain. ${ }^{36}$

Dengan adanya kasus tersebut maka wali yang mengasuh perempuan yatim dilarang mengawininya kecuali jika bisa berlaku adil dan memberinya maskawin lebih tinggi daripada apa yang diberikan oleh laki-laki lain pada umumnya. Para wali yatim tersebut diperintahkan menikahi

\footnotetext{
${ }^{34}$ Musdah Mulia, Pandangan Islam tentang Poligami (Jakarta: LKAJ-SP, 1999), h. 32.

${ }_{35}$ Musdah Mulia, Pandangan Islam tentang Poligami, h. 33.

${ }^{36}$ Nur Chozin, “Poligami Dalam Al-Qur’an,” Mimbar Hukum, (Jakarta: Al-Hikmah, 1996).
} 
perempuan-perempuan lain yang baik bagi mereka (jika mereka khawatir tidak dapat berlaku adil terhadap anak-anak yatim yang ada dalam perwalian mereka). 'Aisyah r.a melanjutkan: sesudah ayat ini (ayat tentang poligami), orang-orang meminta fatwa kepada Rasulullah Saw maka Allah menurunkan ayat lagi:

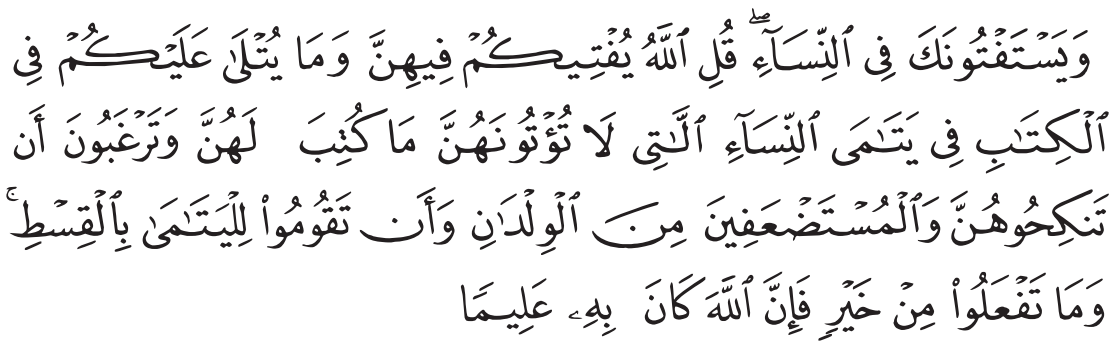

"Dan mereka minta fatwa kepadamu tentang para wanita. Katakanlah: "Allah memberi fatwa kepadamu tentang mereka, dan apa yang dibacakan kepadamu dalam Alquran (juga memfatwakan) tentang para wanita yatim yang kamu tidak memberikan kepada mereka apa yang ditetapkan untuk mereka, sedang kamu ingin mengawini mereka dan tentang anak-anak yang masih dipandang lemah. Dan (Allah menyuruh kamu) supaya kamu mengurus anak-anak yatim secara adil. Dan kebajikan apa saja yang kamu kerjakan, maka Sesungguhnya Allah adalah Maha mengetahuinya".

Turunnya ayat tersebut dikarenakan karena kebiasaan wali yang tidak suka mengawini perempuan yatim dalam perwaliannya yang hartanya hanya sedikit dan tidak seberapa cantik. Dengan demikian, mereka para wali yang mengurus perempuan-perempuan yatim yang menyukai harta dan kecantikan mereka dilarang menikahi mereka kecuali dengan adil, karena seandainya yatim-yatim tersebut hanya berharta sedikit dan tidak menikahi mereka. ${ }^{37}$

Berkenaan dengan illat hukum kebolehan poligami di samping dengan melihat latar belakang sosiologis sebab turunnya ayat tersebut, juga dapat dicermati dari peristiwa poligami Nabi Saw. Nabi Saw melakukan poligami setelah pernikahan pertamanya berlalu sekian lama setelah meninggalnya Khadijah r.a. Rasulullah menikah pada usia 25

${ }^{37}$ Bukhari, Shahih Al-Bukhari (Kairo: Dar Ibn Khuzaimah, 1995), h. 59-60. No: 4574. 
tahun, 15 tahun setelah pernikahan beliau dengan Khadijah r.a., beliau diangkat menjadi Nabi. Isteri beliau ini wafat pada tahun ke 10 kenabian beliau. Ini berarti beliau bermonogami selama 25 tahun. ${ }^{38}$ Tiga atau empat tahun sesudah meninggalnya Khadijah, baru Nabi Saw melakukan awal poligami dengan Aisyah r.a. pada tahun kedua atau ketiga hijriyah. Semua isteri Nabi selain Aisyah adalah para janda yang berusia di atas 45 tahun. Janda-janda yang dikawini oleh nabi, di samping telah mencapai usia senja yang sudah tidak ada daya tarik memikat, juga dalam keadaan sedang mengalami kesusahan hidup karena ditinggal mati suaminya baik mati di medan perang, maupun ditinggal mati biasa dan ada pula dicerai oleh suaminya sebab murtad. Ada pula yang dicerai karena tidak ada kebahagiaan atau ketidakcocokan dengan suaminya. ${ }^{39}$

'Illat hukum kebolehan poligami dalam perkawinan Islam, bukan didorong oleh motivasi seks dan kenikmatan biologis, tetapi oleh motivasi sosial dan kemanusiaan. Hal ini dilakukan oleh perkawinan poligami Nabi Saw dengan beberapa janda pahlawan Islam yang telah lanjut usia seperti Saudah binti Zum'ah (suami meninggal setelah kembali dari hijrah Abessinia), Hafsah binti Umar (suami gugur di perang Badar), Zaenab binti Khuzaemah (suami gugur di perang Uhud), dan Hindun Ummu Salamah (suami gugur di perang Uhud). Isteri-isteri yang lain seperti Ramlah putri Abû Sufyan r.a. diceraikan oleh suaminya yang murtad di perantauan. Huriyah binti al-Haris r.a. adalah putri kepala suku dan termasuk salah seorang yang ditawan pasukan Islam, yang kemudian nabi menikahinya sambil memerdekaannya. Shafiyah binti Huyai r.a., putri pemimpin Yahudi dari Bani Quraidhah yang ditawan setelah kekalahan mereka dalam penegpungan yang dilakukan oleh nabi Saw, diberi pilihan kepada keluarganya atau tinggal bersama Nabi Saw dalam keadaan bebas merdeka. Ia memilih untuk tinggal hidup bersama Nabi

${ }^{38}$ Ini artinya, Nabi Muhammad mempraktikan poligami saat usianya sudah 54 tahun. Padahal jauh sebelumnya, di tengah kebiasaan berpoligami tanpa batas di kalangan masyarakat Arab, Nabi yang saat itu beristrikan Siti Khadijah ra., tetap menganut monogami. Dengan kata lain, poligami dilakukan oleh Nabi tentunya dengan alasan-alasan khusus, yang menurut Prof. M. Quraish Shihab dikiaskan sebagai emergency exit (pintu keluar darurat) dalam pesawat terbang. Lihat M. Quraish Shihab, Perempuan (Jakarta: Lentera Hati, 2005), h. 180-81.

39 Jones, Jamilah, dan Abu Aminah Bilal Philip, Monogami dan Poligami dalam Islam (Jakarta: PT Raja Grafindo Persada, 2001), h. 34. 
Saw. Zaenab binti Jahesy r.a., sepupu Nabi, dinikahkan langsung oleh Nabi dengan bekas anak angkat dan budak beliau, Zaid ibnu Haritsah r.a. Rumah tangga mereka tidak bahagia, sehingga mereka bercerai dan sebagai penanggungjawab pernikahan itu Nabi Saw menikahinya atas perintah Allah Swt. Mereka (para isteri) itu memerlukan perlindungan untuk melindungi jiwa dan agamanya, dan penanggung untuk memenuhi kebutuhan hidupnya. ${ }^{40}$

Artinya, pernikahan nabi setelah wafatnya Khadijah bukan bermaksud untuk melaksanakan nafsu syahwatnya, akan tetapi untuk menjalin kekeluargaan dengan anak dari sahabatnya Abû Bakar, yakni 'Aisyah. Setelah itu baru menikah dengan Hafshah binti 'Umar bin Khattâb, ia adalah seorang janda muda, setelah itu menikah dengan Ummu Salamah, ia adalah janda panglima perang beliau sendiri yang gugur di medan perang sebagai pahlawan syahid. Kemudian menikah dengan Saudah, ia adalah seorang wanita bernasib malang yang tidak mempunyai suami, karena usianya sudah tua.

Sebagai contoh lainnya adalah pernikahan Rasul dengan Zainab binti Jahsyi, pernikahan ini adalah merupakan pernikahan yang berat bagi Rasul karena Zainab itu sendiri mantan dari isteri anak angkatnya sendiri, dan termasuk dari kerabat Rasul sendiri. Juga pernikahan Rasul dengan Ummu Habîbah ia adalah putri dari tokoh dan penguasa Quraisy Makkah yakni Abû Sofyan bin Harb. Jadi pernikahan Rasul setelah wafatnya Khadijah itu pada dasarnya didorong atas rasa dan kondisi mereka semua dan untuk menjalin persauadaraan dengan para sahabatnya. ${ }^{41}$

Berdasarkan pemaparan sosio-historis di atas, dapat dimengerti bahwa teks-teks hadis poligami dan ayat-ayat Alquran sebenarnya mengarah kepada kritik, pelurusan, dan pengembalian pada prinsip keadilan, ${ }^{42}$

${ }^{40}$ Jones, Jamilah, dan Abu Aminah Bilal Philip, h. 35.

${ }^{41}$ Muhammad Al-Ghazali, Figh Sirah, dalam bahasa Indonesia Fiqh Sirah (Menghayati Nilai-Nilai Riwayat Hidup Muhammad Rasulullah Saw), trans. oleh Abu Laila dan Muhammad Tohir (Bandung: Al-Ma’arif, 1998), h. 715-724.

${ }^{42}$ Sebab bila pelaku praktik poligami tidak mengindahkan keadilan dalam berumah tangga, maka akan terkena sanksi di akhirat nanti berdasarkan hadis nabi, yang diriwayatkan dari Abi Hurairah bahwasanya Nabi Saw bersabda : Barangsiapa yang mempunyai dua istri, kemudian ia melebihkan kepada salah satunya, maka ia akan datang di hari kiamat dalam keadaan miring sebelah badannya. Lihat Ahmad, Musnad Ahmad bin Hanbal (Bayrut: Dar al-Fikr, 1978), h. 124. Hadits ini juga diriwayatkan oleh yang empat dengan sanad yang shahih. 
bukan mengarah kepada sunnah atau bahkan kewajiban. Hal ini terlihat dari pernyataan dan sikap Nabi yang sangat tegas menolak poligami 'Ali bin Abi Thalib r.a. Anehnya, teks hadis ini jarang dimunculkan kalangan propoligami. Padahal, teks ini diriwayatkan para ulama hadis terkemuka: Bukhâri, Muslim, Turmudzi, dan Ibn Majah. Nabi Saw. marah besar ketika mendengar putri beliau, Fâthimah binti Muhammad Saw, akan dipoligami 'Ali bin Abi Thalib r.a. Ketika mendengar rencana itu, Nabi pun langsung masuk ke masjid dan naik mimbar, lalu berseru: "Beberapa keluarga Banî Hasyim bin al-Mughirah meminta izin kepadaku untuk mengawinkan putri mereka dengan 'Ali bin Abi Thalib. Ketahuilah, aku tidak akan mengizinkan, sekali lagi tidak akan mengizinkan. Sungguh tidak aku izinkan, kecuali 'Ali bin Abi Thalib menceraikan putriku, kupersilakan mengawini putri mereka. Ketahuilah, putriku itu bagian dariku; apa yang mengganggu perasaannya adalah menggangguku juga, apa yang menyakiti hatinya adalah menyakiti hatiku juga". ${ }^{43}$

\section{Penutup}

Apa yang telah dijelaskan di atas, eksistensi poligami secara normatif telah termaktub dalam Alquran dan hadis. Kualitas hadis yang telah dijelaskan, berdasarkan kasus Qais bin al-Haris dapat dikategorikan sebagai hadis yang shahih. Sementara dari konteks hadis, turunnya hadis tentang pembatasan poligami dikarenakan praktik poligami telah berjalan lama pra Islam datang. Hasil dari pemaparan tentang poligami, terlihat tampak bahwa praktik poligami merupakan sesuatu yang mubah, bukan sunnah apalagi wajib. Dan tujuan adanya poligami adalah untuk mengangkat harkat dan martabat anak yatim yang ditinggal mati orang tuanya (ayahnya). Bahkan bisa dikatakan bahwa teks-teks hadis poligami sebenarnya mengarah kepada kritik, pelurusan, dan pengembalian pada prinsip keadilan, bukan kesewenang-wenangan atau pelampiasan nafsu birahi.

${ }^{43}$ Ibn Asir al-Jazari, Jâmi’ al-Ushûl fi Ahadisi al-Rasul, juz XII, h. 162, nomor hadis: 9026. 


\section{Pustaka Acuan}

Asqalani, Syihabuddin Ahmad bin Ali bin Hajar Al-. Tahdzîb Al-Tahdzîb. Bayrut: Dar al-Fikr, 1995. Dimuraja'ah oleh Sidqi Jamil Al-'Athar, Tahdzîb Al-Tahdzîb, 3. Bayrut: Dar al-Fikr, 1995.

Abdul Wahhab, Ahmad. Ta'addud Nisa al-Anbiya; wa Makanah al-Mar'ah fi al-Yahudiyah wa al-Masiyah wa al-Islam. Kairo: Maktabah Wahbah, 1989.

Abbas, Rafid. "Poligami dalam Kajian Nash Al-Qur'an dan Hadis." EduIslamika 3, no. 1 (Maret 2012): 144.

Abd. Moqsith, "Tafsir Atas Poligami dalam Al-Qur'an”, Karsa 23, No. 1 (Juni 2015): 133-149.

Abdullah, Raihanah. "Berpoligami: Antara Hak Suami dan Hak Isteri Menurut Undang-Undang Keluarga Islam di Malaysia." Jurnal Syariah 11, no. 1 (2003): 131-146.

Chozin, Nur. "Poligami dalam Al-Qur'an.” Mimbar Hukum. Jakarta: Al-Hikmah, 1996.

Dickson, Anne Louis. "Pandangan Ibu-ibu 'Aisyiyah di Malang Terhadap Poligami." Fakultas Ilmu Sosial dan Ilmu Politik. Universitas Muhammadiyah. Malang (2007).

Dewan Redaksi Ensiklopedi Islam, "Ensiklopedi Islam," 4. Jakarta: PT. Ichtiar Baru Van Hoeve, 1994.

Ending, M. "Poligami: Adilkah Kita?[Polygamy: Is it Fair for Us?]." Qawwam: Journal for Gender Mainstreaming 1, no. 1 (2006): 107Á11.

Farhat, Kiram Fahmi. Ta'addud al-Zaujat fi al-Adyan. Kairo: Dar al-Aaq al-Arabiyah, 1971.

Fata, Ahmad Khoirul, and Mustofa Mustofa. "Menyoal Kontekstualisasi Hukum Islam Tentang Poligami." Al-Ulum 13, no. 2 (2013): 415434.

Ghazali, Muhammad Al-. Fiqh Sirah, dalam bahasa Indonesia Figh Sirah (Menghayati Nilai-Nilai Riwayat Hidup Muhammad Rasulullah Saw). trans. oleh Abu Laila dan Muhammad Tohir. Bandung: Al-Ma'arif, 1998. 
Haikal. Rahasia Perkawinan Rasulullah SAW. Jakarta: Rajawali Press, t.t.. Haries, Ahmad. "Poligami dalam Perspektif Ali Asghar Angineer dan Relevansinya dengan Konteks Indonesia Kekinian.” Jurnal Mazahib 4, no. 2 (2007).

Hakim, Amrie. "Poligami, Masalah Krusial dalam Revisi Undang-Undang Perkawinan.” Jurnal Hukum Jentera Online 25 (2003).

Hikmah, Siti. "Fakta Poligami Sebagai Bentuk Kekerasan Terhadap Perempuan." Sawwa: Jurnal Studi Gender 7, no. 2 (2012): 1-20.

Ibnu Majah, Sunan Ibnu Majah, 1. Bayrut: Dar al-Fikr, 2004.

Ilyas, Hamim. "Poligami dalam Tradisi dan Ajaran Islam.” Musawa: Jurnal Studi Gender dan Islam 1, no. 1 (2002): 19-26.

Imron, Ali. "Menimbang Poligami dalam Hukum Perkawinan." Qistie Jurnal Ilmu Hukum 6, no. 1 (2012).

Jahrani, Musfir Husain al-. Poligami dari Berbagai Persepsi, trans. oleh Muh. Suten Ritonga. Jakarta: Gema Insani Press, 2002.

Jalil, Abdul. "Wanita dalam Poligami (Studi Pemikiran Muhammad Syahrur).” Jurnal Cendekia 2, no. 1 (2018).

Jaziry, Abdurrahaman Al-. al-Fiqh Alâ al-Madzâhib al-Arba'ah, IV. Bayrut: Darul Fikr, 1996.

Jazari, Ibn Asir al-. Jâmi al-Ushûl fi Ahadisi al-Rasul, juz XII.

Shihab, M. Quraish. Perempuan. Jakarta: Lentera Hati, 2005.

Jones, Jamilah, dan Abu Aminah Bilal Philip. Monogami dan Poligami dalam Islam. Jakarta: PT Raja Grafindo Persada, 2001.

Khotimah, Ema. "Praktik Pernikahan Poligami pada Istri Ulama: Tinjauan Fenomenologis." Prosiding SNaPP: Sosial, Ekonomi dan Humaniora 1, no. 1 (2017): 93-120.

Mulia, Musdah. Pandangan Islam tentang Poligami. Jakarta: LKAJ-SP, 1999.

Muthahari, Murtadha. Hak-hak Wanita dalam Islam. Jakarta: Lentera, 2001.

Mustaqim, Abdul. "Konsep Poligami Menurut Muhammad Syahrur." Jurnal Studi Ilmu al-Qur'an dan Hadis, vol. 8, 2007) (2007). 
, "Pemikiran Fikih Kontemporer Muhamad Syahrur Tentang Poligami dan Jilbab." Al-Manahij: Jurnal Kajian Hukum Islam 5, no. 1 (2011): 67-80.

Nasri, D. "Perspektif Orang Minang Terhadap Poligami dalam Novel Sitti Nurbaya." Jurnal Multilingual 1 (2010): 93-109.

Noviana, Lia. Persoalan Praktik Poligami dalam Masyarakat Islam. UIN Maulana Malik Ibrahim, t.t.

Noviana, Lia. "Persoalan Praktik Poligami dalam Masyarakat Islam.” Jurnal Salam 15, no. 1 (2012).

Nurohmah, Leli. "Poligami Saatnya Melihat Realitas." Jurnal Perempuan 31 (2003): 31-45.

Poerwadaminta, W.J.S. Kamus Bahasa Indonesia. Jakarta: Balai Pustaka, 1976.

Pitriana, Yuli, and Emi Zulaifah. "Pengetahuan Poligami dalam Islam dan Sikap Terhadap Poligami pada Wanita Muslim.” Psikologika: Jurnal Pemikiran dan Penelitian Psikologi 10, no. 20 (2005).

Poerwandari, Kristi. "Ilusi Poligami." Jurnal Perempuan Menimbang Poligami 31 (2003).

Rajab, Budi. "Meninjau Poligami; Perspektif Antropologis dan Keharusan Mengubahnya.” Jurnal Perempuan 31 (2003): 67-84.

Sajastani, Abû Dawud Sulaiman bin Al-Atsast Al-. Sunan Abi Dawud, 2, Hadis No 2241. Bayrut: Dar al-Fikr, 2003.

Sa’adah, Nurus, Vita Fitria, Kurnia Widiastuti, "Poligami dalam Lintas Budaya dan Agama: Meta-Interpretation Approach.” Asy-Syir'ah Jurnal Ilmu Syariah dan Hukum 49, No. 2, (Desember 2015): 479-499.

Sabiq, Sayyid. Fiqh Sunnah, vol. VI. Bandung: al-Ma’rif, 1990.

Sadnyini, I. A., and Jurnal Studi Jender Srikandi. "Poligami dan Kesengsaraan Perempuan." dalam Jurnal Studi Jender Srikandi 6, no. 1 (2010).

Sunaryo, Agus. "Poligami di Indonesia (Sebuah Analisis NormatifSosiologis)." Yin Yang 5, no. 1 (2010): 143-167. 
Wartini, Atik. "Poligami: dari Fiqh Hingga Perundang-Undangan." HUNAFA: Jurnal Studia Islamika 10, no. 2 (2013): 237-268.

Yilmaz, Ertan, Lut Tamam, and Ufuk Bal. "Polygamy and its Effect on Mental Health/Poligami ve Ruh Sagligina Etkileri." Psikiyatride Guncel Yaklasimlar/Current Approaches to Psychiatry 7, no. 2 (2015): 221-229. 